\title{
Olhares políticos-filosóficos sobre a educação
}

O número 15 da RESAFE apresenta um conjunto de olhares, pensares que têm a política filosófica, a filosofia política, a política como objeto de investigação, que ora parte da ética, ora parte da própria experiência pedagógica para pensar a educação. Se a própria educação é também uma experiência política, uma reflexão a partir desse encontro com o político das práticas educativas aparece não apenas como interessante, mas também importante para as interfaces entre a filosofia e a educação.

As muitas proximidades, mas também as distâncias, entre as experiências educacionais na América do Sul serão o solo desta profusão de olhares que, mesmo dialogando com outros lugares do pensamento, tem nosso Cone Sul como ponto de partida, a nossa vivência.

O primeiro artigo, de Carolina Mamilovich, discute uma abordagem política da educação, articulando elementos de uma filosofia política latino-americana, partindo do discurso pedagógico do primeiro peronismo $e$ analisando duas perspectivas teóricas fortes, na Argentina, para pensar os processos de subjetivação política: a perspectiva liberal-funcionalista e a nacional-populista, colocando em contraste as ideias de consenso e conflito como propostas destas perspectivas. $\mathrm{O}$ artigo de Elnora Gondim e Osvaldino Rodrigues parte da ideia de equilíbrio reflexivo presente na obra de John Rawls para examinar uma possível teoria educacional decorrente da perspectiva rawlsiana, sobretudo em torno do marco da cidadania.

O provocativo ensaio de Filipe Ceppas nos convida a pensar sobre o que ele denomina de desencontros entre ensinar e aprender filosofia através da problematização do ensino por meio da discussão sobre o que significaria transmitir, em seu emaranhado de sentidos, possibilidades e sobre o aprender filosofia (sendo esta pensada como uma atenção), como aprender a "falar em

RIBEIRO, Álvaro Sebastião Teixeira; FLOR DO NASCIMENTO, wanderson. Olhares políticosfilosóficos sobre a educação (Editorial). Revista Sul-Americana de Filosofia e Educação. Número 15, nov/2010-abr/2011, p. 1-2. 
nome próprio", sem uma política necessária de falar por si mesmo sobre o que já se disse na tradição. Por sua vez, o artigo de Inés Moujan se propõe a ler a pedagogia da libertação de Paulo Freire em função do contexto de produção de seu pensamento em seus contornos políticos, tendo como referenciais da contextualização a filosofia da libertação, a história da educação argentina $e$ algumas elaborações conceituais do pensamento descolonial. $\mathrm{O}$ artigo de Ivonei Freitas da Silva e Elisete Tomazetti discute, por sua vez, a obrigatoriedade do ensino de filosofia frente à categoria de jogos casuais de dominação.

Já o artigo de Marcos Alves e Gomercindo Ghiggi parte das reflexões de Emmanuel Levinas, sobretudo em "Totalidade e Infinito", para pensar uma aproximação entre a ética e a educação, apresentando uma crítica possível à pedagogia da Totalidade e verificando a possibilidade de uma pedagogia da Alteridade, que se encaminha da ética para uma possibilidade política. Por fim, o relato de experiência de Alejandra Castagna discute a possibilidade da formação de uma "comunidade de iguais", proposta por Jacques Rancière em "O mestre ignorante", a partir do experimentado em uma escola de gestão social na Argentina.

Que essa partilha de olhares seja um convite para que outros olhares se agreguem, multipliquem e nos façam pensar. Boa leitura!

Álvaro Sebastião Teixeira Ribeiro wanderson flor do nascimento 